Vol. 1, No. 2, Juli - Desember 2017

\title{
edureligia
}

\section{PARADIGMA PENGEMBANGAN KURIKULUM PAI DI LEMBAGA PENDIDIKAN}

\author{
Didiyanto \\ SMP Nurul Jadid
}

\section{Info Artikel}

Sejarah Artikel:

Diterima Maret 2017

Disetujui Mei 2017

Dipublikasikan Juli 2017

Keywords:

curriculum development

paradigm, curriculum

development steps

\section{Abstract}

The curriculum is a teaching and learning tool that needs to be developed in accordance with the existing developments in society. There are 3 kinds of paradigms in curriculum development, among others: 1. Diotomous paradigm, 2. Paradigm nikanisme, 3. Paradigm Organisem. Therefore, curriculum development is the process that determines how the curriculum will work. So in the preparation of curriculum development should consider the steps as follows: Formulation of Objectives; Define Content; Selecting Activities; And Formulate Evaluation. So in the preparation of curriculum development should consider the steps: 1) Formulation of Objectives, 2) Determining Content, 3) Selecting Activities, 4) Formulating Evaluation. 


\section{PENDAHULUAN}

Dalam tataran ideal teoritis, otonomi pendidikan merupakan tuntutan demokratisasi dan perkembangan peradaban serta ilmu pengetahuan dan tekhnologi (Baharun, 2012). Masyarakat ditempatkan pada posisi otonom untuk merancang dan mengelola pendidikan, sehingga diharapkan akan tumbuh suatu format kehidupan masyarakat yang semakin mandiri, kritis dan kreatif, utamanya dalam aktivias pengembangan pendidikan, khususnya pengembangan kurikulumnya.

Pengembangan kurikulum adalah istilah yang komprehensif, didalamnya mencakup perencanaan, penerapan dan evaluasi, yang sesuai dengn Standar Nasional Pendidikan. Kurikulum dapat dipandang sebagai buku atau dokumen yang digunakan guru sebagai pegangan dalam proses belajar mengajar (Islam, 2018)

Standar Nasional Pendidikan disempurnakan secara terencana, terarah, dan berkelanjutan sesuai dengan tuntutan perubahan kehidupan lokal, nasional, dan global. Untuk penjaminan dan pengendalian mutu pendidikan sesuai dengan standar nasional pendidikan dilakukan evaluasi, akreditasi dan sertifikasi. Kualitas pendidikan dapat dilihat dari isi, proses, kompetensi lulusan, pendidik dan tenaga kependidikan, sarana dan prasarana, pengelolaan, pembiayaan, dan penilaian pendidikan (Hasan Baharun, 2017).

Perencanaan kurikulum adalah langkah pertama dalam membangun kurikulum ketika pekerja kurikulum membuat keputusan dan mengambil sebuah tindakan untuk menghasilkan suatu perencanaan yang akan digunakan oleh guru dan peserta didik. Penerapan kurikulum atau biasa disebut juga mengimplementasikan kurikulum berusaha mentransfer perencanaan kurikulum ke dalam tindakan operasional. Pengembangan suatu kurikulum merupakan tahap akhir dari subuah pengembangan kurikulum untuk menentukan seberapa besar hasil-hasil pembelajaran, tingkat ketercapaian program-program yang telah direncanakan dan hasil-hasil kurikulum itu sendiri.

Pada dasarnya pengembangan kurikulum berkisar pada pengembangan aspek Ilmu pengetahuan dan teknologi yang perlu diimbangi perkembangan pendidikan. Manusia, disisi lain sering kali memiliki keterbatasan kemampuan untuk menerima, menyampaikan dan mengolah informasi, karenanya diperlukan proses pengembangan kurikulum yang sangat akurat dan terseleksi dan memiliki tingkat relevansi yang sangat kuat. Dalam hal ini merealisasikannya maka diperlukan suatu model pengembangan kurikulum dengan pendekatan yang sesuai.

\section{PENGERTIAN PENGEMBANGAN KURIKULUM PAI DI PENDIDIKAN}

Kata kurikulum berasal dari bahasa yunani yang semula digunakan dalam bidang olahraga, adalah currere yang berarti jarak tempuh seorang pelari, yaitu suatu jarak yang harus ditempuh dalam kegiatan berlari mulai dari start hingga finish. Pengertian ini kemudian dapat diterapkan di dalam bidang pendidikan (Muhaimin, 2012).

Pengertian kurikulum pendidikan agama Islam yang ada dilembaga pendidikan sebenarnya tidak jauh berbeda dengan kurikulum secara umum, perbedaannya hanya terletak pada sumber pelajarannya saja. Secara tradisional kurikulum dapat diartikan sebagai beberapa mata pelajaran yang diajarkan di sekolah (Baharun, 2017).

Sebagaimana yang diutarakan oleh Abdul Munis dalam bukunya Pembelajaran Agama Islam berbasis Kompetensi, mengatakan bahwa pengembangan kurikulum pendidikan agama Islam adalah suatu rumusan tentang tujuan, materi, metode, dan evaluasi pendidikan yang bersumber pada ajaran agama Islam (Abdul Majid, 2004).

Pendidikan agama Islam adalah upaya sadar dan terencana dalam menyiapkan peserta didik untuk mengenal, memahami diri, menghayati, hingga mengimani ajaran agama Islam, dibarengi dengan adanya tuntunan untuk menghormati penganut suatu agama lain dalam hubungannya dengan kerukunan antar umat beragama hingga terwujudlah kesatuan dan persatuan bangsa. Menurut kami pendidikan agama Islam adalah suatu usaha untuk membina dan mengasuh peserta didik agar senantiasa dapat memahami ajaran Islam secara menyeluruh.

Pengembangan kurikulum adalah suatu kegiatan untuk menghasilkan kurikulum baru melalui langkah penyusunan kurikulum atas dasar dari suatu hasil penilaian yang dapat dilakukan selama periode tertentu, jadi pengembangan kurikulum ini berarti sebuah perubahan dan peralihan dari satu kurikulum ke kurikulum 
lainnya, dan perubahan ini berlangsung dalam waktu panjang (Soetopo \& Wast, 1993).

Dan salah satu komponen penting dari sistem pendidikan adalah kurikulum Karena, kurikulum merupakan peta jalan yang akan menjadi acuan oleh setiap satuan pendidikan, baik pengelola maupun penyelenggara khususnya oleh guru dan kepala sekolah (Siswanto, 2010). And one of the important components of the education system is the curriculum Because the curriculum is a roadmap that will be a reference by any educational institution, both managers and organizers, especially by teachers and principals.

Pengembangan kurikulum adalah dengan perencanaan kesempatan belajar yang dimaksudkan untuk membina siswa atau peserta didik ke arah perubahan perilaku yang diinginkan dan menilai hingga dimana tersebut telah terjadi pada diri siswa yang bersangkutan (Hamalik, 1993). Oleh karena itu, Kurikulum suatu proses perencanaan, yang menghasilkan alat yang lebih baik dengan didasarkan pada hasil penilaian terhadap kurikulum yang telah berlaku, sehingga dapat memberikan kondisi yang sangat lebih baik.

Dari pengertian diatas kami dapat disimpulkan bahwa pengembangan kurikulum menunjuk pada kegiatan menghasilkan kurikulum, kegiatan ini lebih bersifat konseptual daripada material, yang dimaksud dalam pengembangan ini adalah penyusunan, pelaksanaan, penilaian dan penyempurnaan yang selanjutnya menghasilkan kurikulum baru sebagai hasil dari pengembangan yang dilakukan.

Pengembangan kurikulum Pendidikan Agama Islam (PAI) dapat diartikan sebagai kegiatan menghasilkan kurikulum PAI, proses yang mengkaitkan satu komponen dengan komponen lain untuk menghasilkan kurikulum pendidikan agama Islam (PAI) yang lebih baik (Subandiah, 1996).

Dari perbedaan pandangan tersebut, dapat dipahami bahwa pada dasarnya ada 3 tiga pengertian kurikulum yang berkembang hingga saat ini.

- Pertama, Adalah kurikulum diartikan sejumlah mata pelajaran yang disajikan guru kepada peserta didik guna mendapatkan ijazah atau naik kelas. Ini berarti kurikulum dipandang hanya sekedar memuat dan dibatasi pada sejumlah mata pelajaran.

- Kedua, ialah kurikulum dimaksudkan sebagai sejumlah pengalaman dan kegiatan peserta didik, baik di sekolah maupun di luar sekolah, di bawah tanggung jawab guru atau sekolah. Ini berarti kurikulum mencakup pengalaman dan pengetahuan yang bersumber dari kegiatan-kegiatan peserta didik di dalam dan luar kelas.

- Ketiga, Kurikulum adalah sejumlah program pendidikan atau program belajar peserta didik (a plan for learning) yang disusun secara logis dan sistematis, di bawah tanggung jawab sekolah atau guru, guna mencapai tujuan pendidikan sekolah yang telah ditetapkan (Halimah, 2009).

\section{PARADIGMA PENGEMBANGAN PAI DI SEKOLAH/ PERGURUAN TINGGI}

Ada 3 paradigma pengembangan pendidikan agama islam (Siswanto, 2010).

\section{Paradigma Dikotomis}

Didalam paradigma ini, semua aspek kehidupan dipandang dengan 2 sisi yang berbeda dan berlawanan, seperti laki-laki dan perempuan. Dan PAI hanya dipandang sebagai pendidikan yang berkonsentrasi pada bidang agama, ritual dan spritual saja. Implikasi dari paradigma ini peserta didik diarahkan untuk menjadi pelaku (aktor) dan loyal (setia), memiliki sifat komitmen , dan dedikasi yang tinggi terhadap agama yang dipelajari. Sementara kajian-kajian keilmuan yang bersifat empiris , rasional, analitis-kritis, dianggap dapat menggoyahkan iman, sehingga perlu ditindih oleh pendekatan keagamaan yang normatif dan doktriner tersebut.

\section{Paradigma Mekanisme}

Didalam KBBI berarti : hal kerja mesin, cara kerja suatu organisasi, atau hal saling bekerja seperti mesin, yang mssing-masing bergerak sesuai dengan fungsinya. Implikasi dari paradigma ini para guru /dosen agama harus menguasai ilmu agama dan memahami substansi ilmu-ilmu umum, sebaliknya dosen / guru umum dituntut untuk mengeuasai ilmu yang di ampuhnya dan ilmu agama, guru dituntut untuk mampu menyusun buku - buku teks keagamaan yang dapat menjelaskan hubungan antar keduanya.

\section{Paradigma Organism}

Dalam konteks pendidikan islam paradigma organism bertolak dari pandangan bahwa aktivitas kependidikan merupakan suatu sistem yang terdiri atas komponen-komponen yang 
hidup bersama dan bekerja sama secara terpadu menuju tujuan tertentu, yaitu terwujudnya hidup yang religius atau dijiwai oleh ajaran dan nilai-nilai agama.

Paradigma tersebut tampaknya mulai dirintis dan dikembangkan dalam sistem pendidikan di madrasah, yang dideklarasikan sebagai sekolah umum yang berciri khas agama Islam.Dalam hal ini madrasah membuat kebijakan yang terdiri atas 3 kepentingan utama :

- Sebagai wahana membina ruh dan praktik hidup keislaman

- Mempertegas keberadaan madrasah sederajat dengan sistem sekolah, sebagai wahana pembinaan masyarakat yang berkepribadian, berpengetahuan , cerdas dan bermoral

- Mampu merespon tuntutan masa depan, dan menghadapi Era globalisasi.

\section{PROSES PENGEMBANGAN KURIKULUM}

\section{Perencanaan}

a. Visi (pernyataan tentang harapan yang ingin dicapai oleh suatu lembaga pendidikan dalam jangka panjang)

b. Kebutuhan pengguna (pelajar, masyarakat,pengguna lulusan) dan studi lanjut

c. Hasil evaluasi kurikulum sebelumnya dan tuntutan perkembangan iptek juga zaman.

d. Pandangan para Ahli pendidikan

e. Era globalisasi. $=>5$ ide diatas akan dievaluasi untuk di kembangkan menjadi Program berupa Dokumen/Berkas yang berisi : Informasi dan jenis dokumen, Format silabus dan komponen kurikulum yang harus dikembangkan.

2. Implementasi; melakukan sosialisasi dan pengembangan Program berupa pengembangan kurikulum dalam bentuk RPP atau SAP (Satuan Acara Pembelajaran), proses pembelajaran di dalam dan diluar kelas, serta evaluasi pembelajaran untuk mengetahui tingkat efektivitas dan efisiensi Program tersebut.
3. Evaluasi; dari evaluasi ini akan di peroleh feedback (umpan balik) yang akan digunakan dalam penyempurnaan kurikulum berikutnya.

\section{FUNGSI KURIKULUM PAI}

1. Bagi Madrasah yang bersangkutan

a. Alat untuk mencapai tujuan P A I yang diinginkan

b. Pedoman untuk mengatur kegiatankegiatan P A I

c. Menghindari keterulangan yang memboroskan waktu

d. Menjaga kesinambungan

2. Bagi Masyarakat

a. Masyarakat sebagai pengguna lulusan, Oleh karena itu Madrasah / Sekolah harus meengetahui kebutuhan masyarakat dalam konteks pengembangan P A I

b. Kerjasama yang harmonis dalam pengembangan kurikulumPAI dengan Sekolah/Madrasah

\section{PERANAN GURU DALAM PENGEMBANGAN KURIKULUM}

Ada 2 peranan guru dalam pengembangan kurikulum yaitu

1. Peranan guru dalam pengembangan kurikulum yang bersifat sentralisasi, di sini guru tidak mempunyai peranan rancangan dan evaluasi yang bersifat makro mereka berperan dalam kurikulum mikro.

2. Peranan guru dalam pengembangan kurikulum yang bersifat desentralisasi, dimana guru turut berpartisipasi di dalam menyusun kurikulum yang menyeluruh untuk sekolahnya. Di sini guru juga berperan sebagai perencana, pemikir, penyusun, pengembang dan juga pelaksanaan kurikulum (hambatan Pengembangan kurikulum pertama ada pada guru (Abdullah, 1999).

\section{UNSUR KURIKULUM PENDIDKAN ISLAM DI LEMBAGA PENDIDKAN}

1. Goal (Cita-Cita/Tujuan). Tujuan pendidikan nasional dan Tujuan lembaga pendidikan.

2. Matter (Bahan Pelajaran) : Sesuai dengan tujuan, silabus pelajaran, dan pengetahuan ilmiah.

3. Organizing (Strategi Pelaksanaan
Kurikulum). 
4. Evaluating (Evaluasi Kurikulum): Penilaian terhadap Input pelajaran (semua SDA sebelum menempuh program berupa dana, sarana prasarana dan siswa.), Proses pembelajaran, Out put pembelajaran (Penilaian terhadap lulusan pendidikan ) dan Out come pembelajaran (Kemampuan lulusan dalam menjalankan tugas dan tanggung jawab) (Nasution, 2008)

\section{TUJUAN KURIKULUM PAI DILEMBAGA PENDIDIKAN}

Menurut Arifin dalam bukunya "Pendidikan Islam Dalam Arus Dinamika Masyarakat" menyatakan bahwa rumusan tujuan pendidikan agama Islam adalah untuk merealisasikan manusia muslim yang beriman, bertaQwa dan berilmu pengetahuan yang mampu mengabdikan dirinya kepada Sang Khalik dengan sikap dan kepribadian bulat menyerahkan diri kepada-Nya dalam segala aspek kehidupannya dalam rangka mencari keridhoan-Nya.

Secara garis besar tujuan pendidikan agama Islam adalah untuk meningkatkan keimanan, pemahaman, penghayatan dan pengamalan siswa terhadap ajaran agama Islam, sehingga ia menjadi manusia muslim yang bertakwa kepada Allah SWT, serta berakhlak mulia baik dalam kehidupan pribadi, bermasyarakat, berbangsa dan bernegara (Muali, 2016).

Tujuan tersebut tetap berorientasi pada tujuan penyebutan nasional yang terdapat dalam UU No. 20 tahun 2003. Selanjutnya tujuan umum PAI diatas dijabarkan pada tujuan masing-masing lembaga pendidikan sesuai dengan jenjang pendidikan yang ada. Selain itu, pendidikan agama Islam sebagai sebuah program pembelajaran yang diarahkan untuk:

1. Menjaga akidah dan ketakwaan peserta didik

2. Menjadi landasan untuk lebih rajin mempelajari dan mendalami ilmuilmu agama

3. Mendorong peserta didik untuk lebih kritis, kreatif dan inovatif

Menjadi landasan perilaku dalam kehidupan sehari-hari didalam masyarakat. Dengan demikian bukan hanya mengajarkan pengetahuan secara teori semata tetapi juga untuk dipraktekkan atau diamalkan dalam kehidupan sehari hari (membangun etika sosial) (Hamdan, 2009).

\section{PRINSIP-PRINSIP PENGEMBANGAN KURIKULUM}

Sedangkan Asep Herry Hernawan dkk (2002) mengemukakan lima prinsip dalam pengembangan kurikulum, yaitu :

1. Prinsip relevansi; secara internal bahwa kurikulum memiliki relevansi di antara komponen-komponen kurikulum (tujuan, bahan, strategi, organisasi dan evaluasi). Sedangkan secara eksternal bahwa komponen-komponen tersebutmemiliki relevansi dengan tuntutan ilmu pengetahuan dan teknologi (relevansi epistomologis), tuntutan dan potensi peserta didik (relevansi psikologis) serta tuntutan dan kebutuhan perkembangan masyarakat (relevansi sosilogis).

2. Prinsip fleksibilitas; dalam pengembangan kurikulum mengusahakan agar yang dihasilkan memiliki sifat luwes, lentur dan fleksibel dalam pelaksanaannya, memungkinkan terjadinya penyesuaianpenyesuaian berdasarkan situasi dan kondisi tempat dan waktu yang selalu berkembang, serta kemampuan dan latar bekang peserta didik.

3. Prinsip kontinuitas; yakni adanya kesinambungandalam kurikulum, baik secara vertikal, maupun secara horizontal. Pengalaman-pengalaman belajar yang disediakan kurikulum harus memperhatikan kesinambungan, baik yang di dalam tingkat kelas, antar jenjang pendidikan, maupun antara jenjang pendidikan dengan jenis pekerjaan.

4. Prinsip efisiensi; yakni mengusahakan agar dalam pengembangan kurikulum dapat mendayagunakan waktu, biaya, dan sumbersumber lain yang ada secara optimal, cermat dan tepat sehingga hasilnya memadai.

5. Prinsip efektivitas; yakni mengusahakan agar kegiatan pengembangan kurikulum mencapai tujuan tanpa kegiatan yang mubazir, baik secara kualitas maupun kuantitas.

\section{PERAN GURU PAI DI SEKOLAH / MADRASAH}

Guru memegang peran yang sangat penting dalam kegiatan belajar mengajar. Tugas guru sebagai profesi meliputi mendidik, mengajar, dan 
melatih. Mendidik berarti meneruskan dan mengembangkan nilai-nilai hidup (Baharun, 2016a).

Menurut Syaiful Bahri Djamarah dalam bukunya "Guru Dan Anak Didik dalam Interaksi Edukatif", menyebutkan peranan guru agama Islam adalah seperti diuraikan di bawah ini.

\section{Korektor}

Sebagai korektor, guru harus bisa membedakan mana nilai yang baik dan mana nilai yang buruk. Kedua nilai yang berbeda itu harus betul-betul dipahami dalam kehidupan di masyarakat. Kedua nilai ini mungkin telah anak didik miliki dan mungkin pula telah mempengaruhinya sebelum anak didik masuk sekolah. Dalam kehidupan anak didik yang berbeda-beda sesuai dengan sosio-kultural masyarakat dimana anak didik tinggal akan mewarnai kehidupannya.

\section{$>$ Inspirator}

Sebagai inspirator, guru harus dapat memberikan ilham yang baik bagi kemajuan belajar anak didik. Persoalan belajar adalah masalah utama anak didik. Guru harus dapat memberikan petunjuk bagaimana cara belajar yang baik.

\section{Informator}

Guru harus bisa memberikan informasi perkembangan ilmu pengetahuan dan teknologi, selain sejumlah bahan pelajaran untuk setiap mata pelajaran yang telah diprogramkan dalam kurikulum. Untuk menjadi informator yang baik dan efektif, penguasaan bahasalah sebagai kuncinya, ditopang dengan penguasaan bahan yang akan diberikan kepada anak didik. Informator yang baik adalah guru yang mengerti apa kebutuhan anak didik dan mengabdi untuk anak didik.

\section{Organisator}

Sebagai organisator, adalah sisi lain dari peranan yang diperlukan dari guru. Dalam bidang ini guru memiliki kegiatan pengelolaan kegiatan akademik, menyusun tata tertib sekolah, menyusun kalender akademik, dan sebagainya. Semua diorganisasikan sehingga dapat mencapai efektivitas dan efisiensi dalam belajar pada diri anak didik.

\section{Motivator}

Sebagai motivator guru hendaklah dapat mendorong anak didik agar bergairah dan aktif belajar. Dalam upaya memberikan motivasi, guru dapat menganalisis motiv-motiv yang melatarbelakangi anak didik malas belajar dan menurun prestasinya di sekolah. Setiap saat guru harus bertindak sebagai motivator, karena dalam interaksi edukatif tidak mustahil ada diantara anak didik yang malas belajar dan sebagainya. Motivasi dapat efektif bila dilakukan dengan memperhatikan kebutuhan anak didik. Penganekaragaman cara belajar memberikan penguatan dan sebagainya, juga dapat memberikan motivasi pada anak didik untuk lebih bergairah dalam belajar.

\section{Inisiator}

Dalam peranannya sebagai inisiator guru harus dapat menjadi pencetus ide-ide kemajuan dalam pendidikan dan pengajaran.Kompetensi guru harus diperbaiki, keterampilan penggunaan media pendidikan dan pengajaran harus diperbaharui sesuai kemajuan media komunikasi dan informasi abad ini.

\section{$>$ Fasilitator}

Sebagai fasilitator guru hendaknya dapat menyediakan fasilitas yang memungkinkan kemudahan kegiatan belajar anak didik.

\section{$>$ Pembimbing}

Kehadiran guru di sekolah adalah untuk membimbing anak didik menjadi manusia dewasa susila yang cakap.Kekurangmampuan anak didik menyebabkan lebih banyak tergantung pada bantuan guru. Semakin dewasa, ketergantungan anak didik semakin berkurang. Jadi, bagaimanapun juga bimbingan dari guru sangat diperlukan pada saat anak didik belum mampu berdiri sendiri (mandiri).

\section{Pengelola Kelas}

Tujuan umum dari pengelolaan kelas, yaitu menyediakan dan menggunakan fasilitas kelas bagi bermacam-macam kegiatan belajar mengajar agar mencapai hasil yang baik dan optimal. Berdasarkan kondisi demikian sangat diperlukan motivasi dari guru. Kelas yang dikelola dengan baik akan menunjang jalannya interaksi edukatif. Oleh karena itu guru dituntut untuk menguasai pengetahuan yang memadai dan teknik-teknik mengajar yang baik agar ia mampu menciptakan suasana pengajaran yang efektif dan efisien (Baharun, 2015)

\section{$>$ Evaluator}

Sebagai evaluator, guru tidak hanya menilai produk (hasil pengajaran), tetapi juga menilai proses (jalannya pengajaran). Penilaian dalam sistem pembelajaran merupakan suatu proses 
berkelanjutan tentang pengumpulan dan penafsiran informasi untuk menilai (assess) keputusan- keputusan yang dibuat dalam merancang suatu sistem pengajaran (Baharun, 2016b). Dari kedua kegiatan ini akan mendapatkan umpan balik (feedback) tentang pelaksanaan interaksi edukatif yang telah dilakukan.

\section{RUANG LINGKUP KURIKULUM PAI}

Kurikulum hendaknya dikembangkan dengan memegang beberapa prinsip sebagai berikut: (Sya'roni, Zaini, \& Miftah, 2017)

1. Berpusat pada potensi, perkembangan, kebutuhan, dan kepentingan peserta didik dan lingkungan SEKITAR

2. Beragam dan terpadu

3. Tanggap terhadap perkembangan ilmu pengetahuan, teknologi dan seni

4. Relevan dengan kebutuhan kehidupan SEHARI HARI

5. Menyeluruh dan berkesinambungan

6. Belajar sepanjang hayat; Seimbang antara kepentingan nasional dan kepentingan daerah (Sanjaya, 2008).

Selain berpegang teguh pada tujuh prinsip tersebut di atas, pengembangan Kurikulum PAI juga mengacu pada dua belas acuan sebagaimana yang telah diuraikan oleh BSNP sebagai berikut

1. Peningkatan iman dan takwa serta akhlak mulia

2. Peningkatan potensi, kecerdasan, dan minat sesuai dengan tingkat perkembangan dan kemampuan peserta didik

3. Keragaman potensi dan karakteristik daerah dan lingkungan

4. Tuntutan pembangunan daerah dan nasional

5. Tuntutan dunia kerja

6. Perkembangan ilmu pengetahuan, teknologi, dan seni

7. Agama;

8. Dinamika perkembangan global

9. Persatuan nasional dan nilai-nilai kebangsaan
10. Kondisi sosial budaya masyarakat setempat

11. Kesetaraan gender

\section{PENDEKATAN PENGEMBANGAN KURIKULUM PAI DILEMBAGA}

Di dalam teori kurikulum setidak-tidaknya terdapat empat pendekatan yang dapat digunakan dalam pengembangan kurikulum, yaitu : pendekatan subjek akademis; pendekatan humanistis ; pendekatan teknologis ; pendekatan rekonstruksi sosia (Drajat, 1993)

\section{Pendekatan Subjek Akademis}

Pendekatan subjek akademis dalam menyusun kurikulum atau program pendidikan didasarkan pada sistematisasi disiplim ilmu masung-masing. Setiap ilmu pengetahuan memiliki sistematisasi tertentu yang saling berbeda. Misalnya, untuk aspek keimanan atau mata pelajaran akidah menggunakan sistematisasi ilmu tauhid, aspek/mata pelajaran Al-Qur'an menggunakan sistematisasi ilmu Al-Qur'an atau Tafsir, Akhlaq menggunakan sistematisasi ilmu Akhlaq, Ibadah/Muamalah menggunakan sistematisasi Ilmu Fiqih,Tarikh/Sejarah menggunakan sistematisasi Ilmu Sejarah Kebudayaan Islam.

\section{a) Pendekatan Humanistis}

Pendekatan humanistis Dalam kaitannya dengan penentuan strategi pembelajaran PAI, maka pendekatan humanistis lebih menekankan kepada "pembelajaran aktif" dimana dalam proses pembelajaran peserta didik di posisikan sebagai orang yang berpengetahuan dan berpengalaman dan guru sebagai fasilitator yang membimbing dan mengarahkan pembelajaran; memposisikan pelajar sebagai orang yang belajar , mengaktualisasi dan membangun segala potensi-potensi peserta didik.

\section{Pendekatan Teknologis}

Dalam pengembangan kurkikulum PAI , pendekatan tersebut dapat digunakan untuk pembelajaran PAI yang menekankan pada cara menjalankan tugas-tugas tertentu . misalnya cara menjalankan shalat, haji, puasa, zakat, mengkafani mayit, shalat jenazah, dan seterusnya.

\section{Pendekatan Rekonstruksi Sosial}

Dalam menyusun kurikulum pendekatan ini bertolak pada masalah-masalah yang dihadapi masyarakat. Proses pendidikan atau pengalaman peserta didik berbentuk kegiatan-kegiatan belajar kelompok yang mengutamakan kerjasama, antar peserta didik, dan peserta didik dengan guru .Karena itu dalam menyusun kurikulum PAI bertolak dari problem masyarakat sebagai isi PAI 
,sedangkan pengalaman peserta didik adalah dengan cara memerankan ilmuilmu dan teknologi, serta bekerja sama secara berkelompok untuk memecahkan masalah menuju pembentukan masyarakat yang lebih baik.Guru melakukan kegiatan penilaian sepanjang kegiatan belajar.

\section{PENGEMBANGAN KURIKULUM PAI DILEMBAGA PENDIDIKAN}

\section{Asas Asas Pengembangan Kurikulum PAI}

\section{a. Asas Religius (Agama)}

Asas AGAMA ditetapkan berdasarkan nilai-nilai Ilahi yang tertuang dalam alQur'an maupun as-Sunnah, karena kedua kitab tersebut merupakan kebenaran yang universal, abadi dan bersifat futuristik (Majid M. d., 1993). Nabi saw bersabda:"Sesungguhnya aku telah meninggalkan kepadamu yang apabila kalian berpegang teguh kepadanya, maka kalian tidak akan sesat selamanya, yaitu Kitabulla." (H.R Abu Dawud).

Disamping kedua sumber tersebut, dalam pendidikan Islam juga bersumber dalam dalil ijtihad, suatu hasil pemikiran manusia yang tidak berlawanan dengan jiwa dan semangat al-Qur'an dan asSunnah. Dalam ijtihad dapat berupa 'ijma (konsensus para ulama), qiyas (analogi), istihsan, istihsab, mashalikhus mursalah, mazhab sahabi, sadzdzudz dzariah, syar'u man qoblana dan 'urf.

\section{b. Asas Filosofis}

Filsafat suatu bangsa akan sangat mewarnai tujuan pendidikan dalam sistem pendidikan yang dijalankan. Di Indonesia, karena Pancasila telah disepakati dan diyakini bersama sebagai dasar ideal kerohanian negara, hukum dari segala hukum, dasar segala tingkah laku, maka Pancasilalah yang dijadikan dasar acuan dan tujuan pendidikan.

Dengan demikian, asas filosofis Pancasila yang dianut oleh negara kita dengan prinsip demokratis, mengandung makna bahwa peserta didik diberi kebebasan untuk berkembang dan mampu berfikir intelegen dalam kehidupan masyarakat, melakukan aktivitas yang dapat memberikan manfaat terhadap hasil akhir dan menekankan nilai-nilai manusiawi dan kultural dalam pendidikan.

\section{c. Asas Psikologis}

Asas ini memberi arti bahwa kurikulum pendidikan hendaknya disusun dengan mempertimbangkan tahapan-tahapan pertumbuhan anak dan perkembangan yang dilalui anak didik. Kurikulum pendidikan harus dirancang sejalan dengan ciri-ciri perkembangan anak didik, tahap kematangan bakat-bakat jasmani, intelektual, bahasa, emosi dan sosial, kebutuhan dan keinginan, minat, kecakapan, perbedaan individual dan lain sebagainya yang berhubungan dengan aspek-aspek psikologis (Samsul Nizar, 2002).

\section{d. Asas Sosiologis}

Kurikulum diharapkan turut serta dalam proses kemasyarakatan terhadap siswa, penyesuaian mereka dengan lingkungannya, pengetahuan dan kemahiran yang menambah produktifitas dan keikutsertaan mereka dalam membina umat dan bangsanya (Arief, 2002).

Dengan dijadikannya sosiologis sebagai asas atau landasan dalam pengelolaan dan pengembangan kurikulum, maka peserta didik nantinya diharapkan mampu bekerja sesuai dengan kebutuhan masyarakat.

\section{e. Asas Organisatoris}

Hal ini berhubungan dengan masalah pengorganisasian kurikulum, yaitu tentang penyajian mata pelajaran yang harus disampaikan kepada anak.

\section{f. Asas Ilmu Pengetahuan dan Teknologi}

Perkembangan IPTEK akan mempengaruhi perkembangan setiap individu, warga masyarakat, mempengaruhi pengetahuan, kecakapan, sikap, aspirasi, minat, semangat, kebiasaan dan bahkan pola-pola hidup mereka (Majid \& Andayani, 2004). Dengan IPTEK sebagai landasan, peserta didik diharapkan mampu mengikuti perkembangan ilmu pengetahuan dan teknologi dan kesenian sesuai dengan sistem nilai, kemanusiaan dan budaya bangsa.

Mengacu kepada asas-asas pengembangan kurikulum diatas, maka tujuan kegiatan siswa akan menekankan pada pengembangan sikap dan perilaku agar berguna dalam suatu kehidupan masyarakat yang demokratis. Kurikulum bersifat spesifik untuk mencapai kompetensi yang diperlukan dalam melaksanakan pekerjaan tertentu setelah lulus dari sekolah.

\section{Pendekatan Pengembangan Materi Kurikulum}


Pendekatan pengembangan kurikulum adalah cara kerja dengan menerapkan strategi dan metode yang tepat dengan mengikuti langkah-langkah pengembangan yang sistematis untuk menghasilkan kurikulum yang lebih baik. Ada berbagai macam pendekatan yang dapat digunakan dalam mengembangkan materi kurikulum PAI, diantaranya :

\section{a. Pendekatan Keimanan}

Pendekatan keimanan yaitu memberi peluang kepada peserta didik untuk mengembangkan pemahaman adanya Tuhan sebagai sumber kehidupan makluk sejagat ini.

\section{b. Pendekatan Pengalaman}

Pendekatan pengalaman yaitu memberi kesempatan kepada peserta didik untuk mempraktekkan dan merasakan hasil-hasil pengalaman ibadah dan akhlak dalam menghadapi tugas-tugas dan masalah dalam kehidupan sehari-hari.

\section{c. Pendekatan Pembiasaan}

Pendekatan pembiasaan yaitu memberikan kesempatan kepada peserta didik untuk membiasakan sikap dan perilaku yang sesuai dengan ajaran Islam dan budaya bangsa dalam menghadapi masalah kehidupan.

\section{d. Pendekatan Rasional}

Pendekatan rasional yaitu usaha memberikan peranan pada rasio atau akal peserta didik dalam memahami dan membedakan berbagai bahan ajar dalam standar materi serta kaitannya dengan perilaku yang baik dan yang buruk dalam kehidupa duniawi.

\section{e. Pendekatan Emosional}

Pendekatan emosional yaitu upaya menggugah perasaan (emosi) peserta didik dalam menghayati perilaku yang sesuai dengan ajaran agama dan budaya bangsa.

\section{f. Pendekatan Fungsional}

Pendekatan fungsional yaitu menyajikan bentuk semua standar materi (al-qur'an, keimanan akhlak, fiqih atau ibadah dan tarikh) dari segi manfaatnya bagi peserta didik dalam kehidupan sehari-hari dalam arti luas.

\section{g. Pendekatan Keteladanan}

Pendekatan keteladanan yaitu menjadikan figur guru agama dan non agama serta petugas sekolah lainnya maupun orang tua peserta didik sebagai cermin manusia yang berkepribadian.

\section{KESIMPULAN}

Pendidikan agama Islam adalah upaya sadar dan terencana dalam menyiapkan peserta didik untuk bisa mengenal diri, memahami, menghayati, sampai hingga mengimani ajaran agama Islam, dibarengi dengan adanya tuntunan untuk menghormati salah satu penganut agama lain dalam hubungannya dengan kerukunan antar umat beragama hingga terwujud kesatuan dan persatuan bangsa.

Pengembangan kurikulum adalah kegiatan untuk menghasilkan kurikulum baru melalui langkahlangkah penyusunan kurikulum atas dasar hasil penilaian yang dilakukan selama periode tertentu, pengembangan kurikulum berarti perubahan dan peralihan total dari satu kurikulum ke kurikulum lain, dan perubahan ini berlangsung dalam waktu panjang.

Pengembangan kurikulum pendidikan agama Islam (PAI) dapat diartikan sebagai kegiatan menghasilkan kurikulum PAI, proses yang mengkaitkan satu komponen dengan komponen lain untuk menghasilkan kurikulum pendidikan agama Islam (PAI) yang lebih baik.

Secara garis besar (umum) tujuan pendidikan agama Islam adalah untuk meningkatkan keimanan, pemahaman, penghayatan dan pengamalan siswa terhadap ajaran agama Islam, sehingga ia menjadi manusia muslim yang bertakwa kepada Allah SWT, serta berakhlak mulia baik dalam kehidupan pribadi, bermasyarakat, berbangsa dan bernegara.

Kurikulum PAI untuk sekolah atau madrasah berfungsi sebagai Pengembangan, Penanaman Nilai, Penyesuaian Mental, Perbaikan, Pencegahan, Pengajaran dan Penyaluran.

Telah diketahui bahwa setiap kurikulum didasarkan pada sejumlah asas yang akan digunakannya seperti, asas religius (agama), asas filosofis, asas psikologis, asas sosiologis, asas organisatoris dan asas ilmu pengetahuan dan teknologi. Adapun prinsip-prinsip pengembangan kurikulum tersebut, yaitu prinsip relevansi, prinsip efektivitas dan efisiensi, prinsip kesinambungan (continuitas), prinsip fleksibilitas, prinsip berorientasi pada tujuan, prinsip sinkronisasi dan prinsip seumur hidup.

Selain prinsip-prinsip itu, dalam pengelolaan dan pengembangan kurikulum PAI yang berbasis kompetensi juga didasarkan pada prinsip-prinsip yakni prinsip keimanan, nilai, dan budi pekerti luhur, prinsip penguatan integritas nasional, 
prinsip keseimbangan etika, logika, estetika, dan kinestetika, prinsip kesamaan memperoleh kesempatan, prinsip perkembangan pengetahuan dan teknologi informasi, prinsip pengembangan keterampilan hidup, prinsip berpusat pada anak dan prinsip pendekatan menyeluruh dan kemitraan.

Ada berbagai macam pendekatan yang dapat digunakan dalam mengembangkan materi kurikulum PAI, diantaranya pendekatan keimanan, pendekatan pengalaman, pendekatan pembiasaan, pendekatan rasional, pendekatan emosional, pendekatan fungsional dan pendekatan keteladanan. Kegiatan pengembangan materi kurikulum tidak akan lepas dari unsur penilaian. Penilaian merupakan salah satu komponen yang amat penting yang tak dapat diabaikan begitu saja.

Dalam banyak hal, komponen penilaian akan sangat berperan dalam menunjang keberhasilan pengembangan kurikulum tersebut. Informasi yang akurat tentang hasil belajar, minat dan kebutuhan siswa, hanya dapat diperoleh melalui assessment dan evaluasi yang efektif. Hal ini sesuai dengan ketentuan penilaian berbasis kelas $(P B K)$, yang memperhatikan ketiga ranah yaitu kognitif (pengetahuan), afektif (sikap), dan psikomotor (keterampilan). Ketiga ranah ini sebaiknya di nilai secara proporsional sesuai dengan sifat mata pelajaran yang bersangkutan.

\section{DAFTAR PUSTAKA}

Abdullah. (1999). Pengembangan Kurikulum Teori dan Praktik. Jakarta: Gaya Media Pratama.

al-Sijistani, I. a.-K.-'. (1996). . Beirut: Darul Kutub al-Ilmiah.

Arief, A. (2002). Pengantar Ilmu dan Metodologi Islam. Jakarta: Ciputat Pers.

Baharun, H. (2012). Desentralisasi Dan Implikasinya Terhadap Pengembangan Sistem Pendidikan Islam. Jurnal At-Tajdid, 1(2).

Baharun, H. (2015). Penerapan Pembelajaran Active Learning Untuk Meningkatkan Hasil Belajar Siswa Di Madrasah. Jurnal Pendidikan Pedagogik, 1(1), 34-46.

Baharun, H. (2016a). Pengembangan Media Pembelajaran PAI Berbasis
Lingkungan Melalui Model ASSURE. Cendekia: Journal of Education and Society, 14(2), 231-246.

Baharun, H. (2016b). Penilaian Berbasis Kelas pada Pembelajaran Pendidikan Agama Islam di Madrasah. MODELING: Jurnal Program Studi PGMI, 3(2), 205-2016.

Baharun, H. (2017). Pengembangan Kurikulum; Teori dan Praktik (Konsep, Prinsip, Pendekatan dan Langkah-langkah Pengembangan Kurikulum PAI. Yogyakarta: CV Cantrik Pustaka.

Drajat, Z. (1993). Ilmu Pendidikan Islam. Jakarta: Bumi Aksara.

Halimah, S. (2009). Curriculum Development Strategy Islamic Religious Education and Learning (PAI). Miqot, 33(1), 27 - 36.

Hamalik, O. (1993). Sistem dan Prosedur Pengembangan Kurikulum Lembaga Pendidikan dan Pelatihan. Bandung: Trigendi Karya.

Hamdan. (2009). Pengembangan dan Pembinanaan Kurikulum (Teori dan Praktek Kurikulum $P A I)$. Banjarmasin: .

Hasan Baharun, Z. (2017). Manajemen Mutu Pendidikan: Ikhtiar dalam Meningkatkan Mutu Pendidikan Madrasah melalui Pendekatan Balanced Scorecard. Tulungagung: Akademia Pustaka.

Islam, S. (2018). Karakteristik Pendidikan Karakter; MenjawabTantangan Multidimensional Melalui Implementasi Kurikulum 2013, 1(1), 89-101.

Majid, A., \& Andayani, D. (2004). Pendidikan Agama Islam Berbasis Kompetensi. Bandung: Remaja Rosda Karya.

Majid, M. d. (1993). Pemikiran Pendidikan Islam; Kajian Filosofis dan Kerangka Dasar Operasionalisasinya. Bandung: Trigenda Karya.

Muhaimin. (2012). Pengambangan rikulum Pendidikan Agama Islam di Sekolah, Madrasah dan Perguruan Tinggi. Jakarta: Raja Grafindo Persada.

Muali, C. (2016). Konstruksi Strategi Pembelajaran Berbasis Multiple Intelligences Sebagai Upaya Pemecahan Masalah Belajar. Jurnal Pedagogik, 3(2), 111.

Nasution. (2008). Asas-Asas Pengembangan Kurikulum. Jakarta: Bumi Aksara.

Samsul Nizar, A. H. (2002). Filsafat Pendidikan Islam; Pendekatan Historis, Teoritis dan Praktis. Jakarta: Ciputat Pers.

Sanjaya, W. (2008). Kurikulum dan Pembelajaran; Teori dan Praktik Pengembangan Kurikulum Tingkat Satuan Pendidikan (KTSP). Jakarta: Kencana Prenada Media Group. 
Siswanto. (2010). Model Pengembangan Pendidikan Agama Islam di Sekolah. Tadris, 5(2), 107-128.

Soetopo, H., \& Wast. (1993). Pembinaan dan Pengembangan Kurikulum. Jakarta: Bumi Aksara.

Subandiah. (1996). Pengembangan dan Inovasi Kurikulum. Jakarta: Raja Grafindo Persada.

Sya'roni, Zaini, N., \& Miftah, Z. (2017). PAI Curriculum Development Model in Boarding Schools School District Lamongan. Al-Hikmah; Jurnal Studi Keislaman, 7(1), 23-37. 